\title{
Protective Role of Melatonin in Mouse Spermatogenesis Induced by Sodium Arsenite
}

\author{
Rol Protector de la Melatonina en el Daño de la Espermatogénesis \\ en Ratón Producido por Arsenito de Sodio
}

\author{
Eduardo Bustos-Obregón"; Daniel Poblete**; Roberto Catriao ${ }^{* * * *}$ \& Fábio Henrique Fernandes ${ }^{* * * * *}$
}

Bustos-obregón, E.; POBlete, D.; CATRiaO, R. \& FERNANDES, F. H. Protective role of melatonin in mouse spermatogenesis induced by sodium arsenite. Int. J. Morphol., 31(3):849-856, 2013.

SUMMARY: Arsenic is a testicular environmental toxic. Melatonin (Me), being a potent antioxidant, may reduce the damage caused by arsenic in male fertility. The effects of daily oral exposure of Sodium Arsenite (As; $7.0 \mathrm{mg} / \mathrm{kg} / \mathrm{bw}$ ); Melatonin (Me, $10.0 \mathrm{mg} /$ $\mathrm{kg} / \mathrm{bw}) ; \mathrm{Me}(10.0 \mathrm{mg} / \mathrm{kg} / \mathrm{bw})$ plus As $(7.0 \mathrm{mg} / \mathrm{kg} / \mathrm{bw})$, and Negative Control ( $\mathrm{NaCl} 0.9 \%)$ in male CF-1 adult mice were assessed in acute (8.3 days), chronic (33.2 days) and recovery (66,4 days) of testicular damage. We evaluated changes in testicular weight and histopathological, morphometric measurements, expression of COX-2 and Androgen Receptor (AR) antigens and lipid peroxidation levels. Treatment resulted in decreased tubular diameter and AR expression, and increased: interstitial area, luminal diameter, COX-2 expression levels and of lipid peroxidation. Co-administration of As and Me partially decreased germ cell degeneration and AR expression levels, improving testicular histopathological parameters. These results indicate that As causes toxicity and testicular germ cell degeneration by induction of oxidative stress. Me partially protects from this damage in mouse testis, acting as scavenger of oxygen radical species.

KEY WORDS: Mouse; Arsenic; COX-2; Androgen receptor; Oxidative stress; Melatonin.

\section{INTRODUCTION}

Epidemiological studies indicate a connection between human and animal exposure to pollutants that produces effects such as poor semen quality (Saradha \& Mathur, 2006). Many of these contaminants are endocrine disruptors, ie exogenous substances or combinations thereof, that alter the function of the endocrine system and consequently cause adverse health effects in an intact organism, its progeny, or subpopulations (Bustos-Obregón, 2007). Exposure to environmental chemicals such as lead, cadmium and arsenic, are among the main agents in the nature (Migliore \& Coppedè, 2009).

Furthermore, arsenic is a toxic and carcinogenic important chemical that occurs naturally and ubiquitous in the environment (Patlolla \& Tchounwou, 2005) affecting millions of people in the world (Singh \& DuMond, 2007), resulting in a possible route of entry into the food chain (Száková et al., 2009), because it is found in soil, air and water (Singh \& DuMond).
High levels of arsenic in drinking water that exceed the limits of $10 \mathrm{mg} / \mathrm{L}$ set by the World Health Organization (WHO, 2001) and the problems associated with it, can be found in many contries. Chronic exposure to arsenic via drinking water is a major health concern throughout the world (Xie et al., 2004) and has been shown to induce malignant transformation in mammalian cells (Singh \& DuMond).

The cellular mechanism of toxicity of arsenic includes generating reactive oxygen species (ROS). Thus, there is evidence regarding the role of oxidative stress in the etiology of male infertility (Aitken, 1995) and it has been associated with defects in sperm function (Wang et al., 2003) leading to the onset of male infertility (Aitken et al., 1993). For this reason, the application of exogenous antioxidants may have great significance in preventing oxidative damage (Koyuturk et al., 2006).

VID. Universidad de La Frontera, Temuco, Chile.

** Veterinary School, University Santo Tomás, Santiago, Chile,

*** University of Chile Medical School, Santiago, Chile,

***** São Paulo State University, Botucatu, Brazil.

Partially supported by University Snto Tomás (DVM thesis D. Poblete). 
Melatonin (n-acetyl-5-methoxytryptamine) is known as a potent antioxidant and free radical scavenger of ROS (Reiter et al., 2003), but also of reactive nitrogen species (RNS) (Chawla et al., 2008). In mouse, exogenous melatonin preserves spermatogenesis that can be affected by oxidative damage caused by exposure to pesticides which accelerate the production of free radicals and oxidative stress reducing gonadal function (Reiter et al., 2009). Therefore, the administration of melatonin can be a factor effective in preventing the action of testicular toxicants (Patil \& Balaraman, 2009).

Nonetheless, the effect of sodium arsenite on the male reproductive system is not well defined, as well as the assessment of a potential protector role of melatonin against its toxicity. Therefore, the aim of this work was to determine the effects of acute and chronic exposure to sodium arsenite in mouse testis during four and eight cycles of the seminiferous epithelium respectively and evaluate the use of melatonin as a protective antioxidant agent at testicular level.

\section{MATERIAL AND METHOD}

Animals. Three-months-old male mice (Mus musculus) strain CF-1, healthy and sexually mature, were obtained from the Faculty of Medicine, University of Chile. The animals were maintained in a room under controlled conditions of temperature $\left(22 \pm 2^{\circ} \mathrm{C}\right)$, and a $12 \mathrm{~h}$ light/dark cycle, with ad libitum access to commercial pellets and tap water.

Determination of LD50. For conducting this study the LD50 was determined for sodium arsenite (As) orally in male mice, data not found in the literature. For this, we used $30 \mathrm{CF}-1$ male mice (Mus musculus) strain. Five groups of six animals each individually identified for dosing As solution were used. As was dissolved in drinking water of Santiago (Chile) with As not more than $0.01 \mathrm{mg} / \mathrm{L}$ (INN, 2005). This solution exhibit good palatability conditions and was administered orally by tuberculin syringe in a volume not exceeding 0.05 $\mathrm{mL}$ according to the capacity of the animals mouth, always with the same schedule with prior fasting of 4 hours. Tested were five dose levels: 20, 40, 80 and $120 \mathrm{mg} / \mathrm{kg}$ bw/day, leaving 6 control animals receiving only water for treatment.

The animals were observed continuously for the first 24 hours and then daily for a period of fourteen days, recording the deaths and any toxic symptoms presented. The LD50 value was estimated by Probit statistical method, according to the $\%$ of deaths found after receiving a single dose of oral As at different concentrations, resulting in a value of $56.0 \mathrm{mg} / \mathrm{kg} / \mathrm{body}$ weight.
Experimental design. Reproductive changes were studied as acute (8.3 days), chronic (33.2 days) and recovery of testicular damage (66,4 days) in 88 adult mice (Mus musculus) exposed every day to oral doses of Sodium Arsenite (As; 7.0 $\mathrm{mg} / \mathrm{kg} / \mathrm{bw}$, Sigma Chemical Co., St. Louis, MO); Melatonin (Me; $10.0 \mathrm{mg} / \mathrm{kg} / \mathrm{bw}$, Arama Laboratorios SA., Santiago, Chile) (Gultekin et al., 2001); Me (10.0 mg/kg/bw) plus As $(7.0 \mathrm{mg} / \mathrm{kg} / \mathrm{bw})$, and Negative Control ( $\mathrm{NaCl} 0.9 \%)$ delivered orally in a volume not greater than $0.05 \mathrm{~mL}$.

Before the beginning and after the end of treatment, all animals were weighted. Euthanasia was performed by cervical dislocation after anesthesia with ketamine (Laboratory Biosano S.A., Chile) according to the protocol of animal handling of the Bioethics Committee of the Faculty of Medicine, University of Chile.

\section{Testicular Parameters}

Histological and morphometric analysis. After euthanizing the animals, both testicles were removed and separated from epididymis and related tissues. The testes were weighed, the right testicle was reserved for use in biochemical analysis, while the left testis was fixed in aqueous Bouin and subsequently washed in ethanol $70^{\circ}$ and stored until the completion of the routine histological technique and included in Paraplast (Tyco, USA) to obtain cross-sections of $5 \mu \mathrm{m}$.

Serial sections obtained were stained with hematoxylin and eosin for morphometric analysis of epithelial height, tubular diameter, tubular lumen diameter and the percentage of area, per 100 tubules for each mouse. The tissues were observed at 200X and photographed with a digital camera COHU Solid State Camera and processed with the software Image Tool 3.0.

The results for epithelial height, luminal diameter and tubular lumen diameter were measured in microns for each treatment group compared to the control. The interstitial area, expressed in micrones 2 of area not occupied by the tubules in the fields examined in the groups treated were compared with the control groups.

Histopathological analysis of seminiferous tubules. The histopathological analysis was performed of the seminiferous tubules by optical microscope at $1000 \mathrm{X}$ magnification, which primarily evaluated the morphological aspect of the seminiferous tubules that showed tubular tamponade, epithelial vacuolization, cell depletion and tubular atrophy, expressed as a percentage of these tubules altered in treated groups compared to the negative control. Immunohistochemical analysis. Immunohistochemical 
techniques are immunolocalization techniques using an enzyme present in the tissue as an object for labeling. Thus, testicular samples, were mounted on silanized slides and subjected to immunohistochemistry (IHC) to recognize the antigen (COX-2) indirectly, using monoclonal anti-COX-2 (H-62: SC-7951, Santa Cruz Biotechnology) at a dilution of $1: 300$, and the androgen receptor (AR) using monoclonal anti-AR (AN 1-15; ab2742, Abcam) at a 1:500 dilution.

The sections were hydrated in a battery of Xylene (I, II and III) and ethanol $\left(100^{\circ}, 95^{\circ}, 80^{\circ}\right.$ and $\left.70^{\circ}\right)$ to begin the process of antigen retrieval performed in buffer citrate $\mathrm{pH} 6$ for 30 minutes in steamer (Kass et al., 2000), and then cooling at room temperature for 15 minutes and subsequently, moved to a humid chamber. Blocking of endogenous peroxidase was performed with hydrogen peroxide at $5 \%$ for 15 minutes and washed with $1 \mathrm{X}$ PBS twice. To perform blocking a nonspecific protein solution was used (Background Sniper) (B5966H, Biocare Medical, USA) for 15 minutes, washed twice with $1 \mathrm{X}$ PBS and incubated with the primary antibody mentioned above (anti COX-2 or anti-AR), in wet chamber at $4^{\circ} \mathrm{C}$ for 18 hours. After this period, washed twice with $1 \mathrm{X}$ PBS to remove the primary antibody and incubated with biotinylated secondary antibody (Biotinylated Goat Universal link, GU600H, Biocare Medical, USA) for 15 minutes. Then incubated with streptavidin-peroxidase solution (Streptavidin HRP label, HP604H, Biocare Medical, USA) for 15 additional minutes until revealed with the chromogen diaminobenzidine (DAB, DB851D, Biocare Medical) staining intensity being controlled by optical microscope and finally washing with twice distilled water for counterstaining with Harris hematoxylin. The sections were observed under optical microscopy at 400X magnification. 100 tubules were counted for each animal and results were expressed in $\%$ of tubules marked (immunoreactive or positive) for COX-2 or AR in all experimental situations compared with controls.

Determining the levels of lipid peroxidation. To determine the levels of lipid peroxidation thiobarbituric acid (TBA test) assay was used (Buege \& Aust, 1978). For this test, approximately $5 \mathrm{mg}$ of testicular tissue (tunica albuginea free) was resuspended in $1000 \mu \mathrm{L}$ of PBS and incubated at $37^{\circ} \mathrm{C}$ for 60 minutes in the presence of ferrous sulfate and $0.025 \mathrm{mM} 0.125 \mathrm{mM}$ sodium ascorbate. The reaction was stopped with $31.2 \mu \mathrm{L}$ of $100 \%$ TCA for 20 minutes in cold. Then subjected to centrifugation at $1000 \mathrm{~g}$ for 10 minutes to recover the resulting supernatant which was added to 700 $\mu \mathrm{L}$ of $0.67 \% \mathrm{TBA}$ (protected from light), finally to be heated in a water bath at $100^{\circ} \mathrm{C}$ for 20 minutes, cooled again in ice for measuring absorbance at $535 \mathrm{~nm}$ in a Shimadzu Model UV-120-02. Spectrophotometer absorbance values obtained were expressed in Thiobarbituric Acid Reactive Substances
(TBARS, nmol/mg tissue by interpolation from a standard curve of a standard solution of MDA (Merck, Darmstadt, Germany).

The results were expressed as nanomoles of TBARS generated per mg testicular tissue (nmol TBARS / mg tissue) after one hour of incubation at $37^{\circ} \mathrm{C}$ in the presence of $\mathrm{Fe}$ (II)/ascorbate for each experimental group as compared to their respective controls.

Statistical Analisys. All results were expressed as mean \pm standard deviation. Statistical analysis of the results was performed using ANOVA test, nonparametric Kruskal-Wallis test and Dunn's multiple comparison, which allows to compare and determine whether there are significant differences in the results between experimental groups in relation to a control group.

\section{RESULTS}

Morphometric and histopathologic testicular parameters. Morphometric evaluation of the tubular diameter reveals a significant decrease in the animals treated with As in all groups compared to controls ( $p<0.05)$ and significantly increased in the group receiving AsMe, as regarding the 33.2 days ( $\mathrm{p}<0.05$ ). No significant variation was observed in the acute range or recovery of AsMe treated animals.

This variable provides a significant increase in lumen diameter in As exposed animals in all treatment intervals over the control $(\mathrm{p}<0.05)$ and a significant decrease in the AsMe treated groups compared to As at 8.3 days of exposure and 33.2 ( $\mathrm{p}<0.05)$. Only a tendency to decrease in the other treatment intervals was observed.

Epithelial height has a significant decrease in all As treatment groups compared to controls ( $\mathrm{p}<0.05)$. Values are also significant for the groups treated with AsMe from 8.3 to 33.2 days with an increase in epithelial height over the groups subjected to As $(\mathrm{p}<0.05)$. No significant variation was observed in animals treated with AsMe in the range of 66.4 days.

With respect to interstitial area, it was observed a significant increase of the interstitial area in As treated animals with respect to the control $(\mathrm{p}<0.05)$ in all treatment intervals. Only at 33.2 days the interstitial area showed a substantial reduction in the treated group compared to the control AsMe and As ( $\mathrm{p}<0.05)$. No significant variation was observed in the acute or recovery AsMe treated animals (Table I). 
Table I. Values of morphometric parameters, tubular diameter (TD), luminal diameter (LD), epithelial height (EH) and interstitial area (IA) and histopathological analysis (HP) of testicular tissue from mice treated with arsenic, Melatonin, (AsMe) Melatonin plus Arsenic, and Negative Control (N. Control, $\mathrm{NaCl} 0.9 \%$ ) at different times after treatment (a.t.).

\begin{tabular}{llcccc}
\hline Time a.t. & \multicolumn{1}{c}{$\mathrm{TD}(\mu \mathrm{m})$} & $\mathrm{LD}(\mu \mathrm{m})$ & $\mathrm{EH}(\mu \mathrm{m})$ & $\mathrm{IA}\left(\mu \mathrm{m}^{2}\right)$ & $\mathrm{HP}(\%)$ \\
\hline 8.3 days & & & & & \\
Arsenic & $124.7 \pm 3.1^{\mathrm{b}}$ & $66.4 \pm 1.4^{\mathrm{b}}$ & $48.5 \pm 2.9^{\mathrm{b}}$ & $101257.3 \pm 43751.1^{\mathrm{b}}$ & $11.46 \pm 1.7^{\mathrm{b}}$ \\
Melatonin & $158.9 \pm 22.9^{\mathrm{a}}$ & $51.8 \pm 4.3^{\mathrm{a}}$ & $59.1 \pm 0.9^{\mathrm{a}}$ & $52624.5 \pm 12463.1^{\mathrm{a}}$ & $2.26 \pm 1.5^{\mathrm{a}}$ \\
AsMe & $147.2 \pm 3.3^{\mathrm{a}}$ & $52.1 \pm 4.3^{\mathrm{ab}}$ & $60.1 \pm 2.8^{\mathrm{ab}}$ & $76782.2 \pm 45212.1^{\mathrm{a}}$ & $6.26 \pm 1.2^{\mathrm{c}}$ \\
N. Control & $152.3 \pm 23.2^{\mathrm{a}}$ & $60.1 \pm 6.2^{\mathrm{a}}$ & $69.3 \pm 4.3^{\mathrm{a}}$ & $48056.6 \pm 12768.8^{\mathrm{a}}$ & $1.86 \pm 0.5^{\mathrm{a}}$ \\
$\mathbf{3 3 . 2}$ days & & & & & \\
Arsenic & $123.9 \pm 3.2^{\mathrm{b}}$ & $70.5 \pm 2.1^{\mathrm{b}}$ & $45.3 \pm 2.1^{\mathrm{b}}$ & $15062 \pm 24937.2^{\mathrm{b}}$ & $13.75 \pm 1.1^{\mathrm{b}}$ \\
Melatonin & $151.9 \pm 11.2^{\mathrm{a}}$ & $52.0 \pm 1.9^{\mathrm{a}}$ & $57.2 \pm 2.2^{\mathrm{a}}$ & $56324.6 \pm 3988.9^{\mathrm{a}}$ & $6.26 \pm 2.6^{\mathrm{a}}$ \\
AsMe & $143 \pm 11.3^{\mathrm{ab}}$ & $52.3 \pm 2.3^{\mathrm{ab}}$ & $60.4 \pm 1.3^{\mathrm{ab}}$ & $33452.4 \pm 4456.7^{\mathrm{ab}}$ & $3.89 \pm 0.8^{\mathrm{ab}}$ \\
N. Control & $140.2 \pm 10.5 \mathrm{a}$ & $58.9 \pm 4.2^{\mathrm{a}}$ & $64.2 \pm 15.2^{\mathrm{a}}$ & $56289.7 \pm 9465.5 \mathrm{a}$ & $5.12 \pm 2.3^{\mathrm{a}}$ \\
$\mathbf{6 6 . 4}$ days & & & & & \\
Arsenic & $122.3 \pm 4.1^{\mathrm{b}}$ & $65.7 \pm 1.9^{\mathrm{b}}$ & $45.1 \pm 2.7^{\mathrm{b}}$ & $71265.7 \pm 4839.2^{\mathrm{b}}$ & $11.21 \pm 1.6^{\mathrm{b}}$ \\
Melatonin & $175 \pm 2.1^{\mathrm{a}}$ & $54.2 \pm 4.1^{\mathrm{a}}$ & $57.9 \pm 2.8^{\mathrm{a}}$ & $57536.2 \pm 3271.7^{\mathrm{a}}$ & $3.81 \pm 1.2^{\mathrm{a}}$ \\
AsMe & $162.5 \pm 0.9^{\mathrm{a}}$ & $54.5 \pm 5.7^{\mathrm{a}}$ & $63.5 \pm 2.6^{\mathrm{a}}$ & $64787.5 \pm 48946.4^{\mathrm{a}}$ & $3.76 \pm 1.3^{\mathrm{ab}}$ \\
N. Control & $138.9 \pm 10.1^{\mathrm{a}}$ & $57.2 \pm 5.9^{\mathrm{a}}$ & $69.9 \pm 9.5^{\mathrm{a}}$ & $54867.2 \pm 9823.6^{\mathrm{a}}$ & $2.47 \pm 1.4^{\mathrm{a}}$ \\
\hline
\end{tabular}

Data were expressed as mean \pm standard deviation, different letters show significant difference between the groups $(\mathrm{p}<0.05)$.

Table II. Values of immunohistochemical (Cox-2 and Androgen Receptor, AR) and biochemical (Lipid Peroxidation) parameters of testicular tissue from mice treated with arsenic, Melatonin, (AsMe) Melatonin plus Arsenic, and Negative Control $(\mathrm{NaCl} 0.9 \%)$ at different times after treatment (a.t.).

\begin{tabular}{|c|c|c|c|}
\hline Time a.t. & $\begin{array}{c}\text { Cox-2 } \\
\text { (\% positive tubules) }\end{array}$ & $\begin{array}{l}\text { Androgen Receptor } \\
\text { (\% positive tubules) }\end{array}$ & $\begin{array}{c}\text { Lipid Peroxidation } \\
\text { (nM TBARS/mg) }\end{array}$ \\
\hline \multicolumn{4}{|l|}{8.3 days } \\
\hline Arsenic & $11.95 \pm 2.2 \mathrm{a}$ & $09.65 \pm 1.4^{\mathrm{b}}$ & $7.31 \pm 0.9 b$ \\
\hline Melatonin & $11.65 \pm 2.1 \mathrm{a}$ & $12.49 \pm 2.7^{\mathrm{a}}$ & $4.33 \pm 0.3 \mathrm{a}$ \\
\hline AsMe & $11.73 \pm 3.6 \mathrm{a}$ & $11.23 \pm 2.3^{\mathrm{a}}$ & $4.09 \pm 0.7 \mathrm{a}$ \\
\hline Negative Control & $10.31 \pm 2.1 \mathrm{a}$ & $12.92 \pm 1.5^{\mathrm{a}}$ & $4.32 \pm 0.2 \mathrm{a}$ \\
\hline \multicolumn{4}{|l|}{33.2 days } \\
\hline Arsenic & $34.72 \pm 2.6 \mathrm{~b}$ & $10.08 \pm 1.4^{\mathrm{b}}$ & $10.62 \pm 1.3 \mathrm{~b} * * *$ \\
\hline Melatonin & $11.23 \pm 0.7 \mathrm{a}$ & $13.71 \pm 2.6^{\mathrm{a}}$ & $5.52 \pm 0.6^{\mathrm{a}}$ \\
\hline AsMe & $21.43 \pm 1.5^{\mathrm{ab}}$ & $13.98 \pm 1.3 \mathrm{a}^{\mathrm{b}}$ & $8.25 \pm 0.6 \mathrm{a}^{\mathrm{b}}$ \\
\hline Negative Control & $12.28 \pm 1.2 \mathrm{a}$ & $13.62 \pm 1.2^{\mathrm{a}}$ & $5.62 \pm 0.4 \mathrm{a}$ \\
\hline \multicolumn{4}{|l|}{66.4 days } \\
\hline Arsenic & $23.52 \pm 4.1 \mathrm{~b}$ & $12.07 \pm 1.3^{\mathrm{b}}$ & $10.13 \pm 0.3 \mathrm{~b}$ \\
\hline Melatonin & $12.16 \pm 2.3 \mathrm{a}$ & $11.09 \pm 2.3^{\mathrm{a}}$ & $5.09 \pm 1.5 \mathrm{a}$ \\
\hline AsMe & $17.97 \pm 4.2 \mathrm{a}$ & $10.65 \pm 1.8^{\mathrm{a}}$ & $6.87 \pm 1.4 \mathrm{a}$ \\
\hline Negative Control & $12.42 \pm 1.3 \mathrm{a}$ & $12.71 \pm 0.9^{\mathrm{a}}$ & $5.36 \pm 0.5 \mathrm{a}$ \\
\hline
\end{tabular}

Data were expressed as mean \pm standard deviation, different letters show significant difference between the groups $(\mathrm{p}<0.05$, *** $\mathrm{p}<0.001)$. 
Histopathological analysis reveals a significant increase in tubules with alterations in all As treated groups compared to controls ( $\mathrm{p}<0.05)$, describing a time dependent curve. While in the groups submitted to AsMe, there is a tendency to less tubules with acute alterations in the range relative to the control, this being significant at 33.2 days compared to control $(\mathrm{p}<0.05)$, without significant changes at 8.3 or 66.4 days in AsMe treated animals.

Testicular weight has no significant variations in the animals treated with As, AsMe or Me when compared with control groups, in any of the ranges tested: acute, chronic or recovery at 66.4 days.

Immunohistochemical and Biochemical parameters. Immunohistochemical assessment of COX-2 expression showed a pattern similar to the damage observed in As (timedependent) with values significant at 33.2 and 66.4 days of exposure $(\mathrm{p}<0.05)$, showing a trend of increasing tubules (+) from the first cycle compared to controls. In the groups submitted to AsMe, there was a downward trend in its expression, having significant values at 33.2 days compared to the control and As $(\mathrm{p}<0.05)($ Fig. 1).

In relation to Androgen Receptor (AR) expression, we observed a significant decrease in the groups submitted to As in all treatment intervals relative to their controls. In animals treated with AsMe, we observed a significant increase in the expression of 33.2 days with respect to animals subjected to As, in the animals subjected to AsMe, no significant differences were observed in the range of 66.4 days (Table II).

The biochemical analysis of the levels of lipid peroxidation discloses a significantly time-dependent increase significantly of MDA levels in animals exposed to As from 8.3 to 66.4 days compared to control $(\mathrm{p}<0.05)$. While in the animals treated with AsMe there is only a significant decrease in MDA levels in the range of 33.2 days ( $p<0.001)$ compared with the control and with As there is a trend to a decrease in groups subjected to the protective agent at 8.3 and 66.4 days compared to the control, denoting partial protection in all cases (Table II).

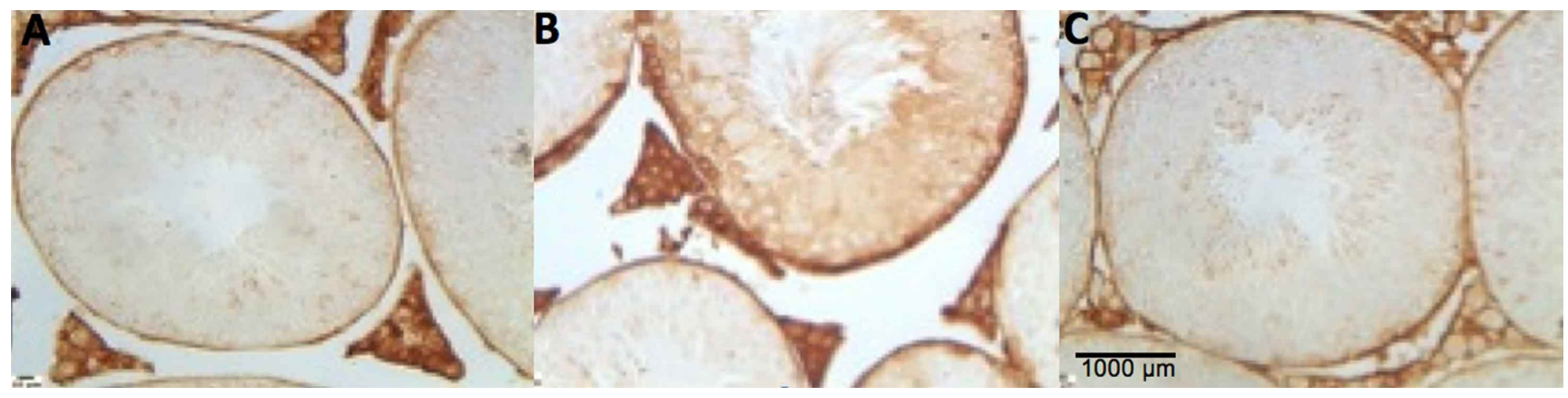

Fig. 1. Immunohistochemical analysis for COX-2 at 33.2 days in seminiferous tubules. negative control (A), sodium arsenite (B) and sodium arsenite plus melatonin $(\mathrm{C})$.

\section{DISCUSSION}

Morphometric and Histopathologic Analysis. Histopathologic and morphometric parameters revealed a total damage of the testis in animals subjected to short long intervals, and recovery after injury, a fact that is characterized by a decrease in epithelial height, a phenomenon that can be explained by decreased proliferation of spermatogonial cells and the subsequent decrease in the number of cell layers, which also are lost by peeling and the presence of slouhing and vacuolated tubules. This is probably due to the loss of tight junctions between the sustentacular cell, and the developing germ cells. The ectoplasmic barrier specialization and hematotesticular barrier has also been shown to be dependent on testosterone (Holdcraft \& Braun, 2004). So, decreased epithelial height, observed over all the intervals of exposure may also be due to an increase in apoptotic index caused by treatment with sodium arsenite (Blanco-Rodriguez \& Martínez-García, 1998) and possibly interstitial cell damage.

This damage is also reported in similar experiences in mice (Sanghamitra et al., 2008) and rats (Mukherjee \& Mukhopadhyay, 2009; Mehranjani \& Hemadi, 2007). They also observed increase in luminal diameter of the seminiferous tubule and of interstitial area in testicular tissue.

Tubular diameter decreased in animals treated with arsenite and matches morphometric parameters evaluated in rats, showing also an increase in luminal diameter, interstitial area increase and decrease in epithelial height, together with a decrease in cell number of interstitial cells (Ahmad et al., 2008). 
The increase in the interstitial area due to treatment with sodium arsenite, is consistent with the reduced tubular diameter which may be due to the activity of prostaglandins in a possible inflammatory process characterized by edema, as reported also for testicular damage caused by pesticides (Raleigh et al., 2004).

In a rat study, it was determined that a dose of $5.0 \mathrm{mg} /$ $\mathrm{kg} / \mathrm{day}$ sodium arsenite, produced lower levels of gonadotropins, intratesticular and plasma testosterone levels, which is directly related to degeneration of the germline. High concentrations of testosterone in the testes are essential for normal development of spermatogenesis and also maintaining the morphological structure and normal physiology of the seminiferous tubules (Sharpe et al., 1998, 1992).

One response that is most common as morphological damage is vacuolization of sustentacular cell, generating germ cell degeneration, disorganization and exfoliation of them (Creasy, 2001).

Melatonin is shown in the present study, as partial protection for morphometric and histological parameters acting on the chronic exposure to sodium arsenite, suggesting that the increased production of reactive oxygen species affects the structural organization of the seminiferous epithelium, which would be associated with decreased proliferation of germ cells. These alterations in the seminiferous epithelium are due to loss of stem cells and can be considered as a sign of apoptosis (Ghasemi et al., 2010).

This may explain the increase in MDA levels observed in treated animals compared to controls, and significant reductions observed in animals treated with sodium arsenite and melatonin, particularly at extended intervals. This suggests that melatonin exerts a prolonged effect through the activation of antioxidant enzyme systems (Reiter et al., 2000).

The testicular weight did not change significantly during all treatment intervals. This could be due to age differences between the animals and the presence of edema, causing a greater weight variation in animals (Pant et al., 2004).

Immunohistochemical parameters. Testicular toxic administration affects the expression of COX-2, which is constitutively expressed in mouse testis. Overexpression observed in this study may be due to decrease in intracellular levels of arachidonic acid (AA) caused by the destruction thereof by the action of ROS, as a compensatory mechanism, which in turn increases the production of PGFa (Astiz et al., 2009).

However, suppression of expression of COX-2 leads to an accumulation of AA, as it plays an important role in the synthesis of steroid hormones. Accumulation could interfere with the production of testosterone and thus causes defects in sperm maturation. Since COX-2 is coexpressed with COX-1, further studies are needed to confirm whether it has other functions with respect to male reproduction (Balaji et al., 2007).

In this study, sodium arsenite decreased expression of the androgen receptor in all treatment intervals. Arsenic inhibits the transcriptional activity of AR in prostate cancer and sustentacular cells using genetic testing assesses for various regions of androgen response elements (ARE). Accordingly, inhibition of AR activity by the arsenic was not caused by a down regulation of AR protein levels, decreased binding to AR hormone, disruption of the nuclear translocation of AR or any interference with AR binding to DNA in vitro, but rather caused disruption of the AR in the interaction of the amino and carboxy termini of the protein (Rosenblatt \& Burnstein, 2009).

Biochemical parameters. The increased production of ROS is associated with a loss of sperm function through mechanisms including lipid peroxidation of membranes, metabolism disorders, motility and sperm fertilizing ability alterations (Wang et al.).

Whereas ROS is increased in the animals treated with As (De Vizcaya-Ruiz et al., 2009), they possess the ability to cause instability of membrane damaging activity of certain signaling pathways involved in metabolic processes. Damage to the integrity of the plasma membrane permeability increase thereof, which leads to inactivation of cellular enzyme systems, structural damage to DNA and cell death (Engel et al., 1999). In this study we observed increases in MDA levels from 8.3 to 66.4 days of treatment, compared to controls, while in AsMe it was observed a significant decrease to 33.2 days compared to control, results consistent with those obtained in a study that evaluated the antioxidant activity of melatonin on MDA generation in ethionine induced fatty liver (Ferraro \& LópezOrtega, 2008).

The lipid peroxidation has been reported in human erythrocytes and on testicular interstitial cells of rat. In the latter, it was possible to establish a relationship between the production of ROS and impaired production of androgens, particularly testosterone (Gultekin et al., 2000).

Melatonin has been shown to have antioxidant effects (Reiter et al., 1997). It has been observed that reduces oxidative stress as measured by TBARS as performed in this study and as observed in other models (Allegra et al., 2003). Furthermore the expression of COX-2 has been linked to increased ROS (Astiz et al.). ROS activity decreases as trapped by Melatonin. However, Melatonin also acts by enhancing the expression of glutathione, and its activity (Ferraro \& López-Ortega). 
Because of its strong antioxidant properties, melatonin protects membrane lipids, proteins in cytosol and mitochondrial DNA free from radical damage (Chowdhury $e t$ al., 2008).

CONCLUSION. Melatonin exerts its antioxidant effect in morphometric and functional parameters, immunohistochemical (COX-2 and AR) and ROS production (lipid peroxidation) by the testis, in a time-dependent manner, reaching its best level of protection for long intervals of 33.2 days (four cycles of the seminiferous epithelium), probably assisted by cell renewal of the seminiferous epithelium.

BUSTOS-ObRegón, E.; POBLETE, D.; CATRIAO, R. \& FERNANDES, F. H. Rol protector de la melatonina en el daño de la espermatogénesis en ratón producido por arsenito de sodio. Int. J. Morphol., 31(3):849-856, 2013.

RESUMEN: El arsénico es un tóxico testicular ambiental. La melatonina (Me), que es un potente antioxidante, puede reducir el daño causado por el arsénico en la fertilidad masculina. Se evaluaron los efectos de la exposición oral diaria de arsenito de sodio (As; 7,0 $\mathrm{mg} / \mathrm{kg} /$ peso corporal), melatonina (Me, $10,0 \mathrm{mg} / \mathrm{kg} / \mathrm{p} . c.) ; \mathrm{Me}(10,0 \mathrm{mg} / \mathrm{kg} / \mathrm{p} . c$.) más As (7,0 mg/kg/pc) y el Control Negativo (NaCl 0,9\%) en ratones adultos CF-1 machos, a los 8,3 días (exposición aguda), 33,2 días (crónica) y 66,4 días (recuperación) del daño testicular. Se evaluaron los cambios en el peso testicular y mediciones morfométricas, histopatológicas, expresión de COX-2, del receptor de andrógeno (AR) y los niveles de peroxidación de lípidos. El tratamiento con As resultó en disminución del diámetro tubular y la expresión de AR, y el aumento de: área intersticial, diámetro luminal, los niveles de expresión de COX-2 y peroxidación lipídica. La coadministración de As y Me disminuyó parcialmente la degeneración de células germinales, el aumento de los niveles de expresión de AR y hubo mejoría de los parámetros histopatológicos testiculares. Estos resultados indican que As es tóxico y causa degeneración de células germinales por inducción de estrés oxidativo. Me protege parcialmente este daño en los testículos de ratones, actuando como eliminador de especies radicalarias del oxígeno.

\section{PALABRAS CLAVE: Ratón; Arsénico; COX-2; Receptor andrógeno; Estrés oxidativo; Melatonina.}

\section{REFERENCES}

Ahmad, I.; Mahmood K. \& Hussain, T. Arsenic induced microscopic changes in rat testis. Professional Med. J., 15(2):287-1, 2008.

Aitken, R. J. Free radicals, lipid peroxidation and sperm function. Reprod. Fertil. Dev., 7(4):659-68, 1995.

Aitken, R. J.; Harkiss, D. \& Buckingham, D. Relationship between ironcatalysed lipid peroxidation potential and human sperm function. J. Reprod. Fertil., 98(1):257-65, 1993.

Allegra, M.; Reiter, R. J.; Tan, D. X.; Gentile, C.; Tesoriere, L. \& Livrea, M. A. The chemistry of melatonin's interaction with reactive species. J. Pineal Res., 34(1):1-10, 2003.

Astiz, M.; Hurtado de Catalfo, G. E.; de Alaniz, M. J. \& Marra, C. A. Involvement of lipids in dimethoate-induced inhibition of testosterone biosynthesis in rat interstitial cells. Lipids, 44(8):703-18, 2009.

Balaji, T.; Ramanathan, M. \& Padmanabhan Menon, V. Localization of cyclooxygenase- 2 in mice testis and assessment of its possible role through suppressing its expression using nimesulide: a preferential cyclooxygenase-2 inhibitor. Prostaglandins Leukot. Essent. Fatty Acids, 76(6):341-8, 2007.

Blanco-Rodríguez, J. \& Martínez-García, C. Apoptosis precedes detachment of germ cells from the seminiferous epithelium after hormone suppression by short-term oestradiol treatment of rats. Int. J. Androl., 21(2):109-15, 1998.

Buege, J. A. \& Aust, S. D. Microsomal lipid peroxidation. Methods Enzymol., 52:302-10, 1978.
Bustos-Obregón, E. Testicular Toxicants. Reviews on Basic Andrology. Kerala, Research Signpost, 2007.

Chawla, S. L.; Yadav, R.; Shah, D. \& Rao, M. V. Protective action of melatonin against fluoride-induced hepatotoxicity in adult female mice. Fluoride, 41(1):44-1, 2008.

Chowdhury, I.; Sengupta, A. \& Maitra, S. K. Melatonin: fifty years of scientific journey from the discovery in bovine pineal gland to delineation of functions in human. Indian J. Biochem. Biophys., 45(5):289-304, 2008.

Creasy, D. Pathogenesis of male reproductive toxicology. Toxicol. Pathol., 29(1):64-7, 2001.

De Vizcaya-Ruiz, A.; Barbier, O.; Ruiz-Ramos, R. \& Cebrian, M. E. Biomarkers of oxidative stress and damage in human populations exposed to arsenic. Mutat. Res., 674(1-2):85-92, 2009.

Engel, S.; Schreiner, T. \& Petzoldt, R. Lipid peroxidation in human spermatozoa and maintenance of progressive sperm motility. Andrologia, 31(1):17-22, 1999.

Ferraro, S. \& López-Ortega, A. Antioxidant activity of Melatonin on fatty liver induced by ethionine in mice. Arch. Med. Vet., 40(1):517, 2008.

Ghasemi, F. M.; Faghani, M.; Khajehjahromi, S.; Bahadori, M.; Nasiri, E. E. \& Hemadi, M. Effect of Melatonin on Proliferative Activity and Apoptosis in Spermatogenic Cells in Mouse under Chemotherapy. J. Reprod. Contracept., 21(2):79-4, 2010. 
Gultekin, F.; Delibas, N.; Yasar, S. \& Kilinc, I. In vivo changes in antioxidant systems and protective role of melatonin and a combination of vitamin $\mathrm{C}$ and vitamin $\mathrm{E}$ on oxidative damage in erythrocytes induced by chlorpyrifos-ethyl in rats. Arch. Toxicol., 75(2):88-96, 2001.

Gultekin, F.; Ozturk, M. \& Akdogan, M. The effect of organophosphate insecticide chlorpyrifos-ethyl on lipid peroxidation and antioxidant enzymes (in vitro). Arch. Toxicol., 74(9):533-8, 2000.

Holdcraft, R. W. \& Braun, R. E. Androgen receptor function is required in Sertoli cells for the terminal differentiation of haploid spermatids. Development, 131(2):459-67, 2004.

INN, Instituto Nacional de Normalización. Agua Potable, Parte 1, Requisitos, NCH 409/1: Of. Santiago, Chile, 2005.

Kass, L.; Varayoud, J.; Ortega, H.; Muñoz de Toro, M. \& Luque, E. H. Detection of bromodeoxyuridine in formalin-fixed tissue. DNA denaturation following microwave or enzymatic digestion pretreatment is required. Eur. J. Histochem., 44(2):185-91, 2000.

Koyuturk, M.; Yanardag, R.; Bolkent, S. \& Tunali, S. Influence of combined antioxidants against cadmium induced testicular damage. Environ. Toxicol. Pharmacol., 21(3):235-40, 2006.

Mehranjani, M. S. \& Hemadi, M. The effects of sodium arsenite on the testis structure and sex hormones in vasectomised rats. Iran. J. Reprod. Med., 5(3):127-3, 2007.

Migliore, L. \& Coppedè, F. Environmental-induced oxidative stress in neurodegenerative disorders and aging. Mutat. Res., 674(1-2):7384, 2009.

Mukherjee, S. \& Mukhopadhyay, P. Studies on Arsenic Toxicity in Male Rat Gonads and its Protection by High Dietary Protein Supplementation. Al Ameen J. Med. Sci., 2(1):73-7, 2009.

Pant, N.; Murthy, R. C. \& Srivastava, S. P. Male reproductive toxicity of sodium arsenite in mice. Hum. Exp. Toxicol., 23(8):399-403, 2004.

Patil, L. \& Balaraman, R. Effect of melatonin on doxorubicin induced testicular damage in rats. Int. J. PharmTech Res., 1(3):879-4, 2009.

Patlolla, A. K. \& Tchounwou, P. B. Serum acetyl cholinesterase as a biomarker of arsenic induced neurotoxicity in sprague-dawley rats. Int. J. Environ. Res. Public Health, 2(1):80-3, 2005.

Raleigh, D.; O'Donnell, L.; Southwick, G. J.; de Kretser, D. M. \& McLachlan, R. I. Stereological analysis of the human testis after vasectomy indicates impairment of spermatogenic efficiency with increasing obstructive interval. Fertil. Steril., 81(6):1595-603, 2004.

Reiter, R.; Tang, L.; Garcia, J. J. \& Muñoz-Hoyos, A. Pharmacological actions of melatonin in oxygen radical pathophysiology. Life Sci., 60(25):2255-71, 1997.

Reiter, R. J.; Tan, D. X.; Mayo, J. C.; Sainz, R. M.; Leon, J. \& Czarnocki, Z. Melatonin as an antioxidant: biochemical mechanisms and pathophysiological implications in humans. Acta Biochim. Pol., 50(4):1129-46, 2003.

Reiter, R. J.; Tan, D. X.; Manchester, L. C.; Paredes, S. D.; Mayo, J. C.
\& Sainz, R. M. Melatonin and reproduction revisited. Biol. Reprod., 81(3):445-56, 2009

Reiter, R. J.; Tan, D. X.; Osuna, C. \& Gitto, E. Actions of melatonin in the reduction of oxidative stress. A review. J. Biomed. Sci., 7(6):444$58,2000$.

Rosenblatt, A. E. \& Burnstein, K. L. Inhibition of androgen receptor transcriptional activity as a novel mechanism of action of arsenic. Mol. Endocrinol., 23(3):412-21, 2009.

Sanghamitra, S.; Hazra, J.; Upadhyay, S. N.; Singh, R. K. \& Amal, R. C. Arsenic induced toxicity on testicular tissue of mice. Indian $J$. Physiol. Pharmacol., 52(1):84-90, 2008.

Saradha, B. \& Mathur, P. P. Effect of environmental contaminants on male reproduction. Environ. Toxicol. Pharmacol., 21(1):34-41, 2006.

Sharpe, R. M.; Donachie, K. \& Cooper, I. Re-evaluation of the intratesticular level of testosterone required for quantitative maintenance of spermatogenesis in the rat. J. Endocrinol., 117(1):1926, 1988.

Sharpe, R. M.; Maddocks, S.; Millar, M.; Kerr, J. B.; Saunders, P. T. \& McKinnell, C. Testosterone and spermatogenesis. Identification of stage-specific, androgen-regulated proteins secreted by adult rat seminiferous tubules. J. Androl., 13(2):172-84, 1992.

Singh, K. P. \& DuMond, J. W. Jr. Genetic and epigenetic changes induced by chronic low dose exposure to arsenic of mouse testicular Leydig cells. Int. J. Oncol., 30(1):253-60, 2007.

Száková, J.; Zídek, V. \& Miholová, D. Influence of elevated content of cadmium and arsenic in diet containing feeding yeast on organisms of rats. Czech J. Anim. Sci., 54(1):1-9, 2009.

Xie, Y.; Trouba, K. J.; Liu, J.; Waalkes, M. P. \& Germolec, D. R. Biokinetics and subchronic toxic effects of oral arsenite, arsenate, monomethylarsonic acid, and dimethylarsinic acid in v-Ha-ras transgenic (Tg.AC) mice. Environ. Health Perspect., 112(12):125563, 2004.

Wang, X.; Sharma, R. K.; Sikka, S. C.; Thomas, A. J. Jr.; Falcone, T. \& Agarwal, A. Oxidative stress is associated with increased apoptosis leading to spermatozoa DNA damage in patients with male factor infertility. Fertil. Steril., 80(3):531-5, 2003.

World Health Organization (WHO). Environmental health criteria 224, Arsenic and Arsenic compounds. $2^{\text {nd }}$ ed. Genova, World Health Organization, 2001.

\section{Correspondence to:}

Prof. Dr. Eduardo Bustos Obregón

University of Chile Medical School

P.O. Box 70061

Santiago- CHILE

Email: ebustos@med.uchile.cl

Received: 11-03-2013

Accepted: 22-04-2013 